$\xi=-1$

\title{
A New Authentication Scheme with Elliptical Curve Cryptography for Internet of Things (IoT) Environments
}

\author{
M Durairaj ${ }^{1 *}$, K Muthuramalingam ${ }^{2}$ \\ ${ }^{1}$ Assistant Professor, School of Computer Science, Engineering and Application, Bharathidasan University \\ ${ }^{2}$ Assistant Professor, School of Computer Science, Engineering and Application, Bharathidasan University \\ *Email: bardmuthu@gmail.com
}

\begin{abstract}
Internet of Things (IoT) consists of a large number of connected objects that are communicating with each other. To support trusted communication between IoT objects, the authentication procedures should be used and applied to the communicating entities. Internet of Things (IoT) is an emerging technology, which makes the remote sensing and control across the heterogeneous network a reality, and has good prospects in industrial applications. As an essential infrastructure, Wireless Sensor Networks (WSNs) play a crucial role in industrial IoT. Due to the resource-constrained feature of sensor nodes, the design of security and efficiency balanced authentication scheme for WSNs becomes a significant challenge in IoT applications. In this paper, an anonymous authentication scheme for WSNs in an Internet of Things environments.
\end{abstract}

Keywords: Internet of Things, Authentication Scheme, Wireless Sensor Networks, Gate Way Node, Sensor Node, User.

\section{Introduction}

In the early $90 \mathrm{~s}$, the word internet is used to express the technology of connecting computers all over the globe using wired or wireless links. Since then the internet has been effectively used for files sharing, web browsing, e-commerce, social media, etc. However, recent development and deployment of smart technologies have emerged the need for objects to be ubiquitously connected. Consequently, this necessitates the need for more sophisticated techniques to support new machine-to-machine (M2M) communication. To evolve a new world of connected objects, the Internet of Things (IoT) has introduced as the future of the internet $[1,2]$.

The development of IoT has many influences on human life. Human lifestyle is gradually changing toward smartness and intelligence which can be facilitated by the development of smart homes and smart communities as a part of the IoT [3]. Moreover, IoT applications support different daily activities such as route planning, navigation, transportation decisions, traffic and healthcare monitoring, elderly and children supervision, and many more [4].

As is the future of the Internet, the provision of security services, such as authentication, is an essential factor to encourage people to use new technologies and securely access various IoT resources. Users would not be convenient to share and exchange their data and personal information unless protection schemes are used to prevent any malicious behavior. Therefore, efficient security and authentication techniques are necessary for comprehensive and fast deployment of IoT.

\section{Related Works}

Table 1 gives the associated works carried out in the authentication process of the Internet of Things (IoT) environments. Cloud services are considered as the vital part of the IoT since it handles the full range of data.

Table 1: Related Works on Authentication techniques

\begin{tabular}{|l|l|l|l|}
\hline \multicolumn{1}{|c|}{$\begin{array}{l}\text { Author } \\
\text { Name }\end{array}$} & Paper Title & \multicolumn{1}{|c|}{$\begin{array}{l}\text { Methods or } \\
\text { Steps used }\end{array}$} & \multicolumn{1}{|c|}{ Description } \\
\hline $\begin{array}{l}\text { Moghad } \\
\text { dam, } \\
\text { Faraz } \\
\text { Fatemi, } \\
\text { et al [1] }\end{array}$ & $\begin{array}{l}\text { A scalable } \\
\text { and effi- } \\
\text { cient user } \\
\text { authentica- } \\
\text { tion scheme } \\
\text { for cloud } \\
\text { computing } \\
\text { environ- } \\
\text { ments }\end{array}$ & $\begin{array}{l}\text { Modified Dif- } \\
\text { fie-Hellman } \\
\text { Agent } \\
\text { (MDHA), ZKP }\end{array}$ & $\begin{array}{l}\text { In this paper, } \\
\text { client-based user } \\
\text { authentication } \\
\text { agent has been } \\
\text { introduced to } \\
\text { confirm an identi- } \\
\text { ty of the user on } \\
\text { the client side. }\end{array}$ \\
\hline $\begin{array}{l}\text { Singh, } \\
\text { Ashish, } \\
\text { and } \\
\text { Kakali } \\
\text { Chatter- } \\
\text { jee [2] }\end{array}$ & $\begin{array}{l}\text { Autti-tier } \\
\text { authentica- } \\
\text { tion scheme } \\
\text { in cloud } \\
\text { computing } \\
\text { environ- } \\
\text { ment }\end{array}$ & $\begin{array}{l}\text { Multi-tier au- } \\
\text { thentication }\end{array}$ & $\begin{array}{l}\text { This paper pro- } \\
\text { poses a reliable } \\
\text { and more ad- } \\
\text { vanced multi-tier } \\
\text { authentication } \\
\text { scheme for access- } \\
\text { ing cloud services }\end{array}$ \\
\hline $\begin{array}{l}\text { Yang, } \\
\text { Jen Ho, } \\
\text { and Pei } \\
\text { Yu Lin }\end{array}$ & $\begin{array}{l}\text { An ID- } \\
\text { based user } \\
\text { authentica- } \\
\text { tion scheme } \\
\text { [3] cloud } \\
\text { for computing }\end{array}$ & $\begin{array}{l}\text { One way hash } \\
\text { function, XOR } \\
\text { operation }\end{array}$ & $\begin{array}{l}\text { This paper intro- } \\
\text { duces a new ID- } \\
\text { based user authen- } \\
\text { tication scheme } \\
\text { for cloud compu- } \\
\text { ting has proposed. }\end{array}$ \\
& & $\begin{array}{l}\text { The authors } \\
\text { proved that the }\end{array}$ \\
\hline
\end{tabular}




\begin{tabular}{|c|c|c|c|}
\hline & & & $\begin{array}{l}\text { proposed scheme } \\
\text { has higher security } \\
\text { levels and lower } \\
\text { computation costs. }\end{array}$ \\
\hline $\begin{array}{l}\text { Tien-Ho } \\
\text { Chen, } \\
\text { Hsiu-lien } \\
\text { Yeh, } \\
\text { Wei- } \\
\text { Kuan } \\
\text { Shih [4] }\end{array}$ & $\begin{array}{l}\text { An Ad- } \\
\text { vanced } \\
\text { ECC Dy- } \\
\text { namic ID- } \\
\text { Based } \\
\text { Remote } \\
\text { Mutual } \\
\text { Authentica- } \\
\text { tion } \\
\text { Scheme for } \\
\text { Cloud } \\
\text { Computing } \\
\end{array}$ & $\begin{array}{l}\text { Elliptic Curve } \\
\text { Cryptosystem } \\
\text { (ECC) }\end{array}$ & $\begin{array}{l}\text { This paper pro- } \\
\text { poses an ECC } \\
\text { dynamic ID-based } \\
\text { remote mutual } \\
\text { authentication } \\
\text { scheme for remote } \\
\text { devices to solve } \\
\text { the issues. }\end{array}$ \\
\hline $\begin{array}{l}\text { Tsai, Jia- } \\
\text { Lun, and } \\
\text { Nai-Wei } \\
\text { Lo [5] }\end{array}$ & $\begin{array}{l}\text { A privacy- } \\
\text { aware } \\
\text { authentica- } \\
\text { tion scheme } \\
\text { for distrib- } \\
\text { uted mobile } \\
\text { cloud com- } \\
\text { puting } \\
\text { services }\end{array}$ & $\begin{array}{l}\text { bilinear pairing, } \\
\text { One-way hash } \\
\text { function }\end{array}$ & $\begin{array}{l}\text { This paper pro- } \\
\text { poses the trusted } \\
\text { Smart Card Gen- } \\
\text { erator (SCG) } \\
\text { service is not } \\
\text { involved in indi- } \\
\text { vidual user au- } \\
\text { thentication pro- } \\
\text { cess. The proposed } \\
\text { scheme reduces } \\
\text { authentication } \\
\text { processing time } \\
\text { required by com- } \\
\text { munication and } \\
\text { computation be- } \\
\text { tween cloud ser- } \\
\text { vice providers and } \\
\text { traditional trusted } \\
\text { third party service. } \\
\text { Formal security } \\
\text { proof and perfor- } \\
\text { mance analyses } \\
\text { are conducted to } \\
\text { show that the } \\
\text { scheme is both } \\
\text { secure and effi- } \\
\text { cient. }\end{array}$ \\
\hline $\begin{array}{l}\text { Powell, } \\
\text { Court- } \\
\text { ney, } \\
\text { Takashi } \\
\text { Aizawa, } \\
\text { and } \\
\text { Masahar } \\
\text { u } \\
\text { Muneto } \\
\text { mo [6] }\end{array}$ & $\begin{array}{l}\text { Design of } \\
\text { an SSO } \\
\text { Authentica- } \\
\text { tion Infra- } \\
\text { structure } \\
\text { for Hetero- } \\
\text { geneous } \\
\text { Inter-cloud } \\
\text { Environ- } \\
\text { ments }\end{array}$ & $\begin{array}{l}\text { single sign-on } \\
(\mathrm{SSO})\end{array}$ & $\begin{array}{l}\text { This paper out- } \\
\text { lines the plan of an } \\
\text { authentication } \\
\text { infrastructure for } \\
\text { linking distributed } \\
\text { heterogeneous } \\
\text { cloud systems } \\
\text { managed by dif- } \\
\text { ferent cloud man- } \\
\text { agement middle- } \\
\text { ware to enable } \\
\text { them to interoper- } \\
\text { ate as an integrat- } \\
\text { ed inter-cloud } \\
\text { system. This au- } \\
\text { thentication infra- } \\
\text { structure achieves } \\
\text { single sign-on } \\
\text { (SSO), which } \\
\text { allows users to log } \\
\text { in once and access } \\
\text { the various cloud } \\
\text { systems without } \\
\text { being asked to log } \\
\text { in again at each } \\
\text { operation. }\end{array}$ \\
\hline $\begin{array}{l}\text { Peng, } \\
\text { Siwei [7] }\end{array}$ & $\begin{array}{l}\text { An Id- } \\
\text { based Mul- } \\
\text { tiple Au- } \\
\text { thentication } \\
\text { scheme } \\
\text { against } \\
\text { attacks in } \\
\text { wireless } \\
\text { sensor } \\
\text { networks }\end{array}$ & $\begin{array}{l}\text { Symmetrical } \\
\text { Encryption }\end{array}$ & $\begin{array}{l}\text { This paper pre- } \\
\text { sents a novel au- } \\
\text { thentication } \\
\text { scheme to prevent } \\
\text { these attacks. This } \\
\text { Id-based Multiple } \\
\text { Authentication } \\
\text { (IMA) scheme } \\
\text { based upon the } \\
\text { mutual identity } \\
\text { authentication and }\end{array}$ \\
\hline
\end{tabular}

\begin{tabular}{|c|c|c|c|}
\hline & & & $\begin{array}{l}\text { steganography to } \\
\text { give a secure } \\
\text { mechanism for } \\
\text { data aggregation } \\
\text { in WSNs. }\end{array}$ \\
\hline $\begin{array}{l}\text { Nguyen, } \\
\text { Tien } \\
\text { Dung, } \\
\text { and Eui- } \\
\text { Nam } \\
\text { Huh [8] }\end{array}$ & $\begin{array}{l}\text { A Dynamic } \\
\text { ID-Based } \\
\text { Authentica- } \\
\text { tion } \\
\text { Scheme for } \\
\text { M2M } \\
\text { Communi- } \\
\text { cation of } \\
\text { Healthcare } \\
\text { Systems }\end{array}$ & $\begin{array}{l}\text { Probabilistic } \\
\text { Key manage- } \\
\text { ment }\end{array}$ & $\begin{array}{l}\text { This paper pro- } \\
\text { posed a simple } \\
\text { architecture M2M } \\
\text { service apply any } \\
\text { hospital which } \\
\text { considers the } \\
\text { mobility of doc- } \\
\text { tors and patients. } \\
\text { An efficient secu- } \\
\text { rity scheme with } \\
\text { dynamic ID-based } \\
\text { authentication } \\
\text { using crucial } \\
\text { pairwise distribu- } \\
\text { tion is involved in } \\
\text { the M2M system. } \\
\text { It can be assured } \\
\text { high security } \\
\text { through security } \\
\text { analysis under } \\
\text { shared key attack } \\
\text { and Sybil attack. }\end{array}$ \\
\hline $\begin{array}{l}\text { Chu, } \\
\text { Fuzhi, et } \\
\text { al [9] }\end{array}$ & $\begin{array}{l}\text { An im- } \\
\text { proved } \\
\text { identity } \\
\text { authentica- } \\
\text { tion scheme } \\
\text { for the } \\
\text { internet of } \\
\text { things in } \\
\text { heteroge- } \\
\text { neous net- } \\
\text { working } \\
\text { environ- } \\
\text { ments }\end{array}$ & $\begin{array}{l}\text { Elliptical Curve } \\
\text { Cryptography }\end{array}$ & $\begin{array}{l}\text { This paper pro- } \\
\text { poses an identity } \\
\text { authentication } \\
\text { scheme based on } \\
\text { identity authenti- } \\
\text { cation scheme } \\
\text { based on elliptic } \\
\text { curve algorithm } \\
\text { for public and } \\
\text { private key pair to } \\
\text { meet the security } \\
\text { requirements of } \\
\text { the Internet of } \\
\text { Things in hetero- } \\
\text { geneous network- } \\
\text { ing environments. }\end{array}$ \\
\hline $\begin{array}{l}\text { Liu, Jing, } \\
\text { Yang } \\
\text { Xiao, } \\
\text { and CL } \\
\text { Philip } \\
\text { Chen } \\
\text { [10] }\end{array}$ & $\begin{array}{l}\text { Authentica- } \\
\text { tion and } \\
\text { access } \\
\text { control in } \\
\text { the internet } \\
\text { of things }\end{array}$ & $\begin{array}{l}\text { Elliptical Curve } \\
\text { Cryptography, } \\
\text { Role-based } \\
\text { Access Control }\end{array}$ & $\begin{array}{l}\text { This paper mainly } \\
\text { analyzes existing } \\
\text { authentication and } \\
\text { access control } \\
\text { methods, and then, } \\
\text { it designs a feasi- } \\
\text { ble one for the } \\
\text { Internet of Things. }\end{array}$ \\
\hline $\begin{array}{l}\text { Jan, } \\
\text { Mian } \\
\text { Ahmad, } \\
\text { et al [11] }\end{array}$ & $\begin{array}{l}\text { A robust } \\
\text { authentica- } \\
\text { tion scheme } \\
\text { for observ- } \\
\text { ing re- } \\
\text { sources in } \\
\text { the internet } \\
\text { of things } \\
\text { environ- } \\
\text { ment }\end{array}$ & $\begin{array}{l}\text { Symmetrical } \\
\text { Cryptography, } \\
\text { XOR operation }\end{array}$ & $\begin{array}{l}\text { This paper pro- } \\
\text { poses a light- } \\
\text { weight mutual } \\
\text { authentication } \\
\text { scheme which } \\
\text { validates the iden- } \\
\text { tities of the partic- } \\
\text { ipating devices } \\
\text { before engaging } \\
\text { them in communi- } \\
\text { cation for the } \\
\text { resource observa- } \\
\text { tion. }\end{array}$ \\
\hline
\end{tabular}

\section{Proposed Authentication Scheme for the Internet of Things}

A new authentication scheme has proposed for securing the IoT environments. An Elliptical Curve Cryptography system has used to strengthening the encryption and decryption process $[12,13]$. This authentication scheme is composed of two main phases. i) Registration phase, ii) Login and Authentication phase. 


\subsection{Registration Phase}

This registration phase has formed two stages. The first stage is the registration between the user and the gateway, and the second stage is the registration between the sensor node and the gateway.

Table 2: Plain points in the Elliptical Curve Cryptography

\begin{tabular}{|c|c|}
\hline Pmsg(X) & Pmsg(Y) \\
\hline 54 & 3151 \\
\hline 19 & 2118 \\
\hline 37 & 3236 \\
\hline 75 & 3398 \\
\hline 145 & 3322 \\
\hline 127 & 3051 \\
\hline 110 & 36 \\
\hline 93 & 1787 \\
\hline
\end{tabular}

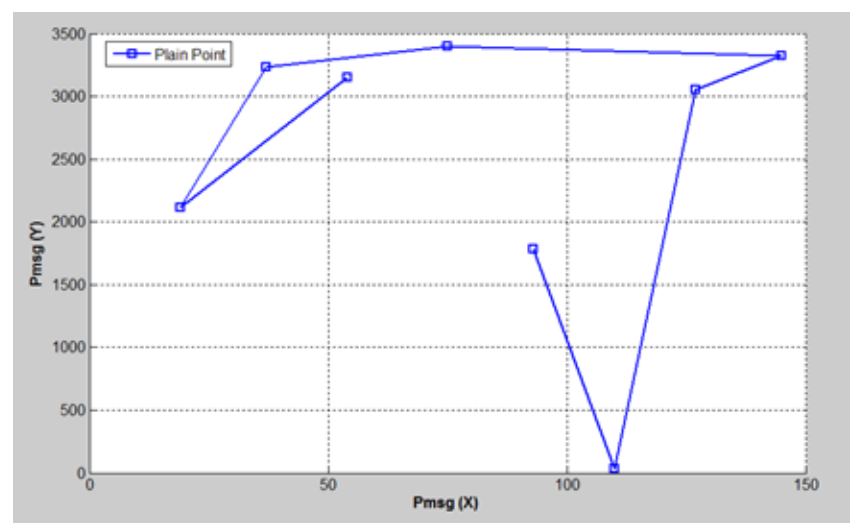

Fig.1: Plain Points in Elliptical Curve

Registration between user - gateway and sensor-gateway

Step 1: The user U selects the ID and password and picks the random integer $b$ from the key pool for key generation using Elliptical Curve Cryptography. The Sensor S selects its ID and generates the random number $\mathrm{y}$.

Step 1.1: The user selects a random number dA between the range [1, n-1].It is the private key of the user.

Step1.2: Then the user generates the public key using the formula $P A=d A * G$

Step 1.3: Similarly gateway selects a private key $\mathrm{dB}$ and generates its public key $\mathrm{PB}=\mathrm{dB} * \mathrm{G}$.

Step 1.4: The user generates the security key $\mathrm{K}=\mathrm{dA}$ $\mathrm{PB}$ and the gateway also receives the security key $\mathrm{K}=\mathrm{dB} * \mathrm{PA}$

Step 2: The user and sensor create the pair of signing and verifying keys and send a message to the Gateway. To sign a message $\mathrm{m}$ by the user, it performs the following steps: $\mathrm{e}=\mathrm{HASH}(\mathrm{m})$

Step 2.1: It calculates a cryptographic hash function $[1, \mathrm{n}-1]$

Step 2.2: The user then selects a random integer k from

Step 2.3: The it computes a pair $(\mathrm{r}, \mathrm{s})$

Step 2.4: $\mathrm{r}=\mathrm{x} 1(\bmod \mathrm{n})$ where $(\mathrm{x} 1, \mathrm{y} 1)=\mathrm{k}^{*} \mathrm{G}$

Step 2.5: $\mathrm{s}=\mathrm{k}-1(\mathrm{e}+\mathrm{dA} * \mathrm{r})$

Step 2.6: This pair $(\mathrm{r}, \mathrm{s})$ defines the signature.

Step 2.7: The signature has sent to the gateway.

Step 3: Gateway stores the values, and sets the pair of private and public keys.

Step 4: Gateway computes the value of the password regarding ciphertext and sends a message to the user. The password of user and sensor can be converted into ciphertext using ECC encryption algorithm.

Step 4.1: Let $\mathrm{m}$ has any point $\mathrm{M}$ on the elliptic curve.

Step 4.2: The user and sensor node select a random number $\mathrm{k}$ from $[1, \mathrm{n}-1]$.
Step 4.3: The ciphertexts generated will be the pair of points (B1, B2) where

$$
\begin{aligned}
& \mathrm{B} 1=\mathrm{k} * \mathrm{G} \\
& \mathrm{B} 2=\mathrm{M}+(\mathrm{k} * \mathrm{G})
\end{aligned}
$$

Step 5: When the user receives message stores value in Smart Card (SC).

Table 3: Cipher points in the ECC

\begin{tabular}{|c|c|}
\hline Cmsg (X) & Cmsg (Y) \\
\hline 2705 & 8245 \\
\hline 2818 & 745 \\
\hline 2516 & 524 \\
\hline 5156 & 1835 \\
\hline 4764 & 7718 \\
\hline 1915 & 6728 \\
\hline 3338 & 987 \\
\hline 6569 & 6442 \\
\hline
\end{tabular}

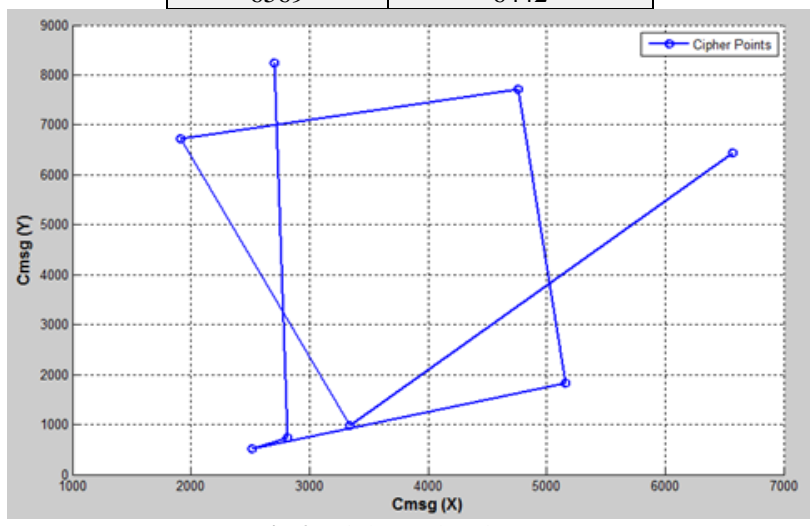

Fig.2: Cipher points in ECC

\subsection{Login and Authentication Phase}

Once the registration process got over, the user has to communicate with the sensor node via the gateway.

Step 1: User inserts Smart Cart into the terminal, and inputs the user id and password.

Step 2: It computes the values and compares the values with the SC.

Step 3: User selects the secret key from the Key pool using ECC.

Step 4: Then user computes the value using secret key and ciphertext.

Step 5: Then it generates the signature and sends the message to the Gateway.

Step 6: When the gateway node receives the message from the user and restores its secret value.

Step 7: It extracts the secret key from the value. The decryption process is carried out using this secret key. private key.

Step 7.1: The gateway computes the product of $\mathrm{B} 1$ and its

Step 7.2: Then the gateway subtracts this product from the second point $\mathrm{B} 2$.

$$
\begin{aligned}
& M=B 2-(d B * B 1) \\
& M \text { is the original data sent by the user. }
\end{aligned}
$$

Step 8: The ciphertext has decrypted, and it verifies the signature with the secret key for authenticating the user.

Step 8.1: For authentication, the gateway needs to verify the pair $(\mathrm{r}, \mathrm{s})$ are in the range of $[1, \mathrm{n}-1]$.

Step 8.2: The gateway again calculates the hash function e as in signature generation.

Step 8.3: Then the gateway calculates $\mathrm{w}=\mathrm{s}-1 \bmod (\mathrm{n})$.

n) Step 8.4: Then calculate $\mathrm{u} 1=\mathrm{e}^{*} \mathrm{w}(\bmod \mathrm{n})$ and $\mathrm{u} 2=\mathrm{r}^{*} \mathrm{w}(\bmod$

Step 8.5: Calculate $(\mathrm{x} 1, \mathrm{y} 1)=\mathrm{u} 1 * \mathrm{G}+\mathrm{u} 2 * \mathrm{PA}$.

Step 8.6: If $\mathrm{x} 1=\mathrm{r}(\bmod \mathrm{n})$, then the signature is valid.

Step 9: If the signature is not valid, then again repeat the process from step 1. 


\section{Result and Discussion}

In this paper, Elliptical Curve Cryptography provides two essential services for securing the IoT environments.

- Securing the Information: It has provided by using encryption and decryption.

- Authenticating the Information: Digital Signature has used for providing the authentication.

In this paper, Elliptical Curve Cryptography has utilized to ensure the security of the information and authenticating the user, sensor and gateway node in the Internet of Things environments.

This paper implements the proposed authentication scheme with ECC and RSA to analyze the performance of the scheme. Three data inputs of 8 bits, 64 bits, and 256 bits are considered based on the ECC and recommendation of NIST.

Table 4: NIST Recommended Security Bit Level

\begin{tabular}{|c|l|l|}
\hline Security Bit Level & ECC & RSA \\
\hline 80 & 160 & 1024 \\
\hline 112 & 224 & 2048 \\
\hline 128 & 256 & 3072 \\
\hline 192 & 384 & 7680 \\
\hline 256 & 512 & 15360 \\
\hline
\end{tabular}

Table 5a: 8bits Encryption Time for ECC and RSA Algorithms in proposed Authentication Scheme

\begin{tabular}{|c|c|c|}
\hline \multirow{2}{*}{ Security Bit Level } & \multicolumn{2}{|c|}{ Encryption Time in Seconds } \\
\cline { 2 - 3 } & ECC & RSA \\
\hline 80 & 0.4776 & 0.0406 \\
\hline 112 & 2.2121 & 0.0288 \\
\hline 128 & 3.7874 & 0.0416 \\
\hline 192 & 4.6377 & 0.0497 \\
\hline
\end{tabular}

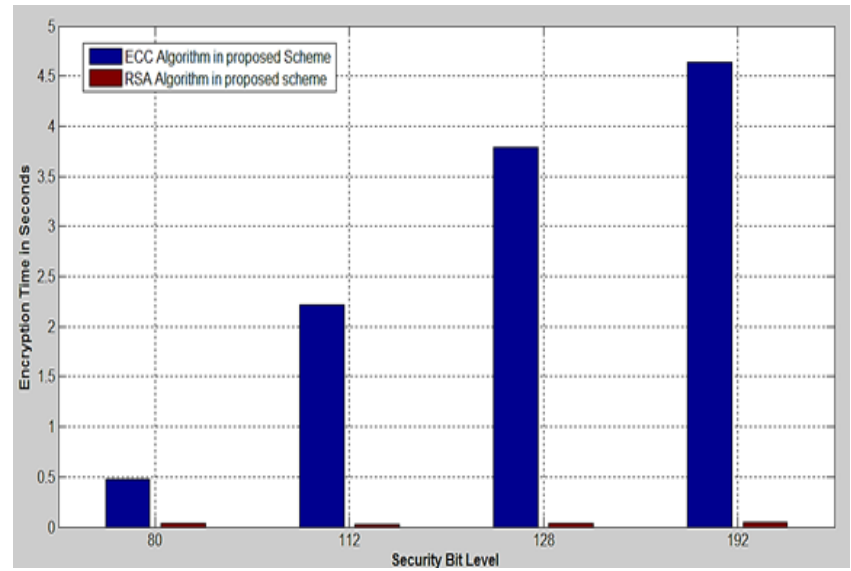

Fig.3a: 8bits Encryption Time for ECC and RSA algorithm in proposed Authentication scheme for various security bit levels

Table 5b: 8bits Decryption Time for ECC and RSA Algorithms in proposed Authentication Scheme

\begin{tabular}{|c|c|c|}
\hline \multirow{2}{*}{ Security Bit Level } & \multicolumn{3}{|c|}{ Decryption Time in Seconds } \\
\cline { 2 - 3 } & ECC & RSA \\
\hline 80 & 1.4376 & 0.8634 \\
\hline 112 & 1.6774 & 2.8186 \\
\hline 128 & 1.8781 & 6.8518 \\
\hline 192 & 2.1133 & 12.5563 \\
\hline
\end{tabular}

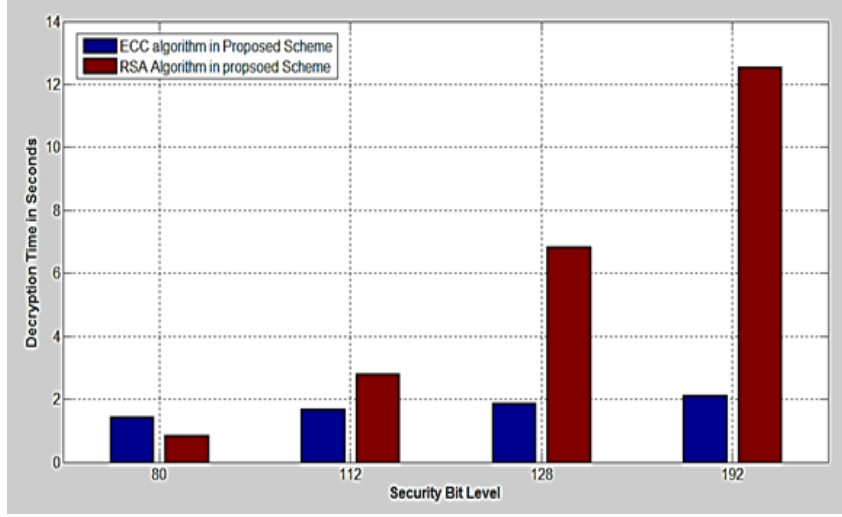

Fig.3b: 8bits Decryption Time for ECC and RSA algorithm in proposed Authentication scheme for various security bit levels

Table 5c: 8bits Total Encryption and Decryption Time for ECC and RSA Algorithms in proposed Authentication Scheme

\begin{tabular}{|c|c|c|}
\hline \multirow{2}{*}{ Security Bit Level } & \multicolumn{2}{|c|}{ Total Time in Seconds } \\
\cline { 2 - 3 } & ECC & RSA \\
\hline 80 & 1.9152 & 0.904 \\
\hline 112 & 3.8791 & 2.8474 \\
\hline 128 & 5.6655 & 6.8934 \\
\hline 192 & 6.7510 & 12.606 \\
\hline
\end{tabular}

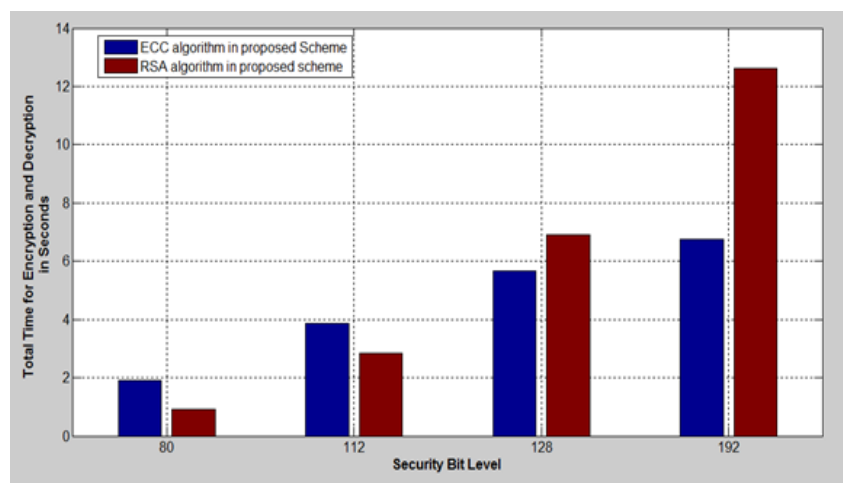

Fig.3c: 8bits Total Encryption and Decryption Time for ECC and RSA algorithm in proposed Authentication scheme for various security bit levels

Above table, 5a gives the encryption time of Elliptical Curve Cryptography and RSA in the proposed authentication scheme for IoT environment. Table $5 \mathrm{~b}$ represents the decryption time of ECC and RSA in proposed scheme and table 5c depicts the total encryption and decryption time for various security bit levels. Considering the above tables, ECC takes more time for encryption and decryption for lower security bits levels (80 and 112 bits), whereas, for higher security bit levels, RSA takes more time for executing the encryption and decryption. Figure $3 a, 3 b$, and $3 c$ give the graphical representation of the 8bits encryption, decryption and total time of ECC and RSA in the proposed authentication scheme for various security bit levels.

Table 6a: 64bits Encryption Time for ECC and RSA Algorithms in proposed Authentication Scheme

\begin{tabular}{|c|c|c|}
\hline \multirow{2}{*}{ Security Bit Level } & \multicolumn{2}{|c|}{ Encryption Time in Seconds } \\
\cline { 2 - 3 } & ECC & RSA \\
\hline 80 & 2.2776 & 0.2455 \\
\hline 112 & 9.8966 & 0.1746 \\
\hline 128 & 15.1771 & 0.2763 \\
\hline 192 & 20.1419 & 0.2496 \\
\hline
\end{tabular}




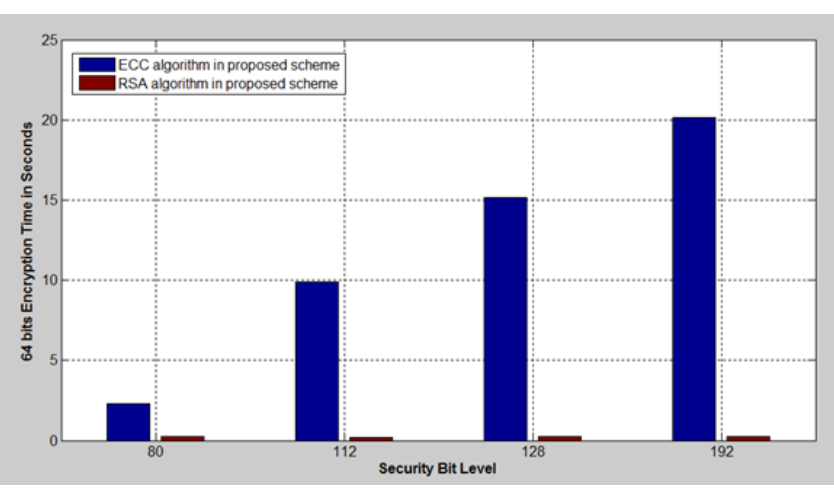

Fig. 4a: 64 bits Encryption Time for ECC and RSA algorithm in proposed Authentication scheme for various security bit levels

Table 6b: 64 bits Decryption Time for ECC and RSA Algorithms in proposed Authentication Scheme

\begin{tabular}{|c|c|c|}
\hline \multirow{2}{*}{ Security Bit Level } & \multicolumn{2}{|c|}{ Decryption Time in Seconds } \\
\cline { 2 - 3 } & ECC & RSA \\
\hline 80 & 5.8188 & 5.6281 \\
\hline 112 & 6.8444 & 20.3217 \\
\hline 128 & 7.4493 & 45.5691 \\
\hline 192 & 7.5896 & 76.6553 \\
\hline
\end{tabular}

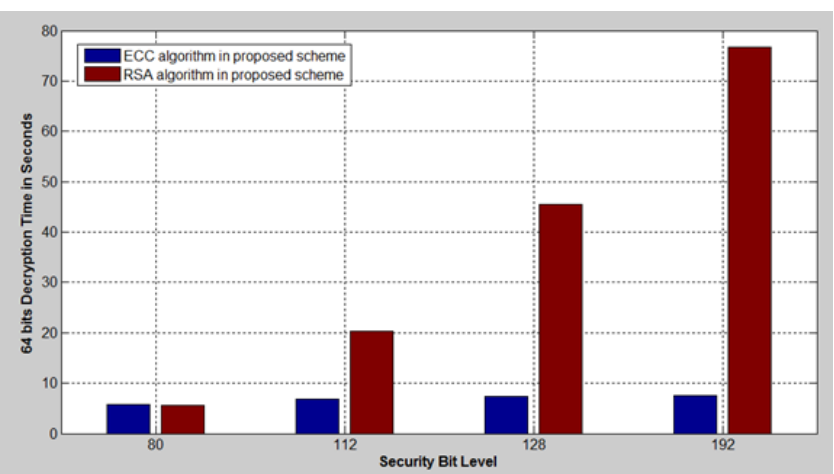

Fig.4b: 64 bits Decryption Time for ECC and RSA algorithm in proposed Authentication scheme for various security bit levels

Table 4c: 64 bits Total Encryption and Decryption Time for ECC and RSA Algorithms in proposed Authentication Scheme

\begin{tabular}{|c|c|c|}
\hline \multirow{2}{*}{ Security Bit Level } & \multicolumn{2}{|c|}{ Total Time in Seconds } \\
\cline { 2 - 3 } & ECC & RSA \\
\hline 80 & 8.0964 & 5.8736 \\
\hline 112 & 16.741 & 20.4963 \\
\hline 128 & 22.6264 & 45.8494 \\
\hline 192 & 27.7315 & 76.9049 \\
\hline
\end{tabular}

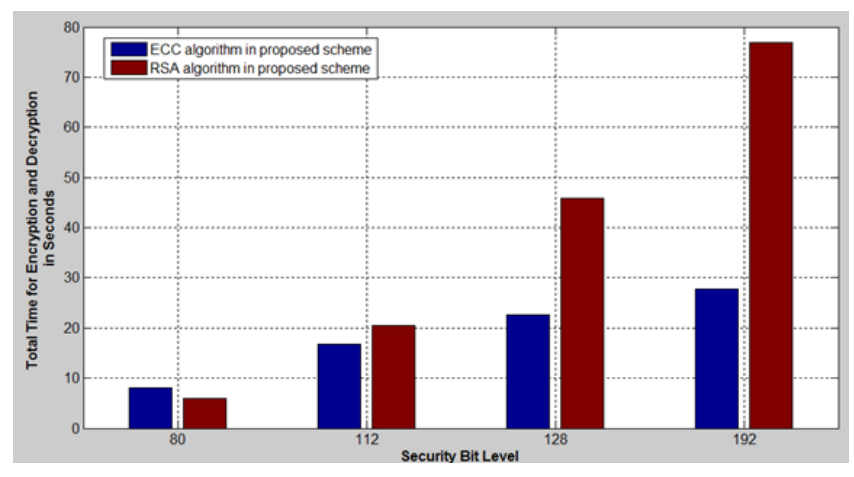

Fig. 4c: 64 bits Total Encryption and Decryption Time for ECC and RSA algorithm in proposed Authentication scheme for various security bit levels

Above table, 6a gives the 64bits encryption time of Elliptical Curve Cryptography and RSA in the proposed authentication scheme for IoT environment. Table $6 \mathrm{~b}$ represents the 64 bits decryption time of ECC and RSA in proposed scheme and table $6 \mathrm{c}$ depicts the total encryption and decryption time of 64bits for various security bit levels. Considering the above tables, ECC takes more time for encryption and decryption for lower security bits levels (80 and 112 bits), whereas, for higher security bit levels, RSA takes more time for executing the encryption and decryption. Figure $4 \mathrm{a}, 4 \mathrm{~b}$, and $4 \mathrm{c}$ give the graphical representation of the 64bits encryption, decryption and total time of ECC and RSA in the proposed authentication scheme for various security bit levels.

Table 7a: 256 bits Encryption Time for ECC and RSA Algorithms in proposed Authentication Scheme

\begin{tabular}{|c|c|c|}
\hline \multirow{2}{*}{ Security Bit Level } & \multicolumn{2}{|c|}{ Encryption Time in Seconds } \\
\cline { 2 - 3 } & ECC & RSA \\
\hline 80 & 7.8331 & 0.6687 \\
\hline 112 & 38.8117 & 0.4926 \\
\hline 128 & 57.5477 & 0.6522 \\
\hline 192 & 76.6145 & 0.6829 \\
\hline
\end{tabular}

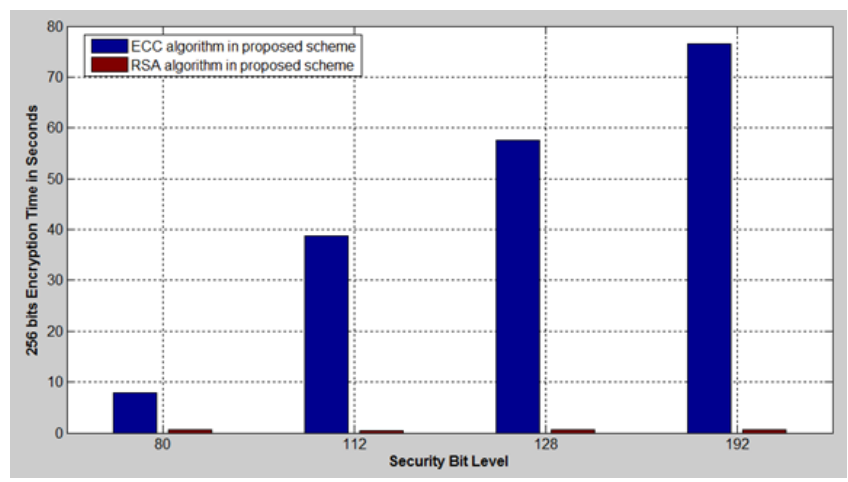

Fig.5a: 256 bits Encryption Time for ECC and RSA algorithm in proposed Authentication scheme for various security bit levels

Table 7b: 256 bits Decryption Time for ECC and RSA Algorithms in proposed Authentication Scheme

\begin{tabular}{|c|c|c|}
\hline \multirow{2}{*}{ Security Bit Level } & Encryption Time in Seconds \\
\cline { 2 - 3 } & ECC & RSA \\
\hline 80 & 21.9962 & 18.4266 \\
\hline 112 & 25.4442 & 103.1446 \\
\hline 128 & 26.5171 & 208.7175 \\
\hline 192 & 31.2633 & 310.1758 \\
\hline
\end{tabular}

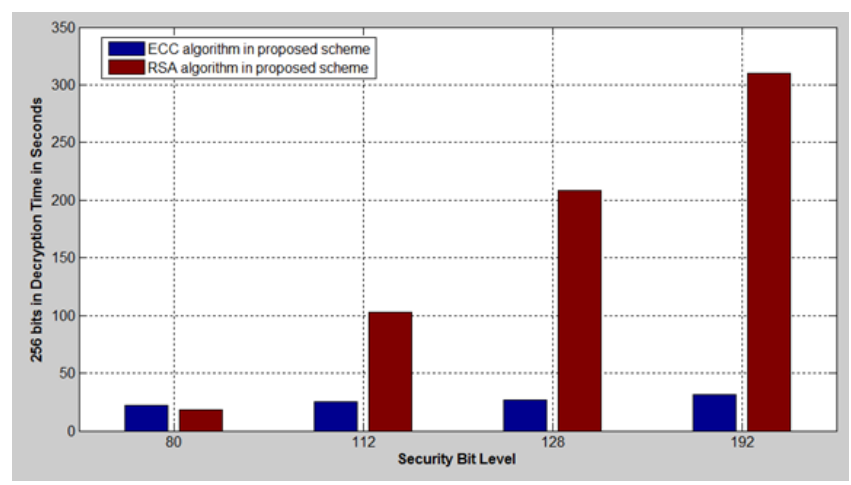

Fig.5b: 256 bits Decryption Time for ECC and RSA algorithm in proposed Authentication scheme for various security bit levels 
Table 7c: 256 bits Total Time of Encryption and Decryption for ECC and RSA Algorithms in proposed Authentication Scheme

\begin{tabular}{|c|c|c|}
\hline \multirow{2}{*}{ Security Bit Level } & \multicolumn{2}{|c|}{ Encryption Time in Seconds } \\
\cline { 2 - 3 } & ECC & RSA \\
\hline 80 & 29.8293 & 103.8133 \\
\hline 112 & 64.2559 & 103.6372 \\
\hline 128 & 84.0648 & 209.3697 \\
\hline 192 & 107.8778 & 310.8587 \\
\hline
\end{tabular}

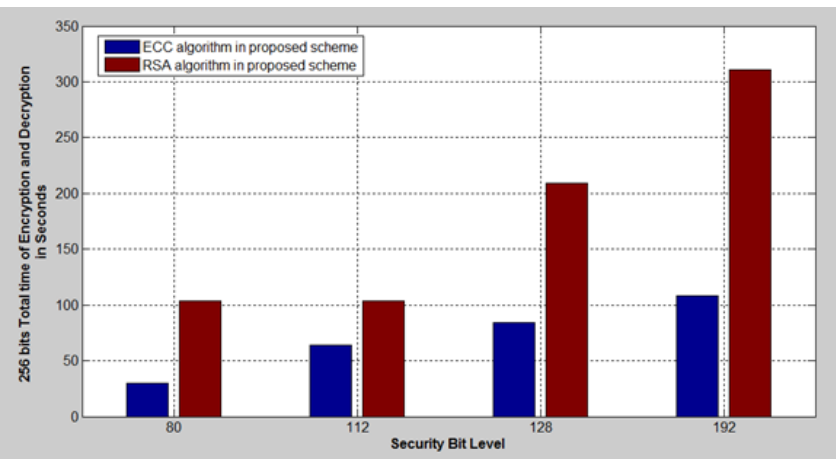

Fig.5c: 256 bits Total time of Encryption and Decryption for ECC and RSA algorithm in proposed Authentication scheme for various security bit levels

Above table, 7a gives the 64bits encryption time of Elliptical Curve Cryptography and RSA in the proposed authentication scheme for IoT environment. Table $7 \mathrm{~b}$ represents the 256 bits decryption time of ECC and RSA in proposed scheme and table 7c depicts the total encryption and decryption time of 256 bits for various security bit levels. Considering the above tables, ECC takes more time for encryption and decryption for lower security bits levels ( 80 and 112 bits), whereas, for higher security bit levels, RSA takes more time for executing the encryption and decryption. Figure $5 \mathrm{a}, 5 \mathrm{~b}$, and $5 \mathrm{c}$ give the graphical representation of the 256 bits encryption, decryption and total time of ECC and RSA in the proposed authentication scheme for various security bit levels.

\section{Conclusion}

In this paper, a new authentication scheme with Elliptical Curve Cryptography (ECC) scheme in the context of the Internet of Things (IoT). The proposed authentication scheme composed of two phases: i) Registration phase and ii) Login and an Authentication phase. ECC takes less time for decryption than RSA in the higher security level. ECC performs in less total time for Encryption and decryption of details among User, Gateway, and Sensor nodes. When it has compared with the various security bit levels, the proposed authentication scheme with ECC algorithm outperforms than the proposed scheme with RSA.

\section{References}

[1] Moghaddam, Faraz Fatemi, et al. "A scalable and efficient user authentication scheme for cloud computing environments." Region 10 Symposium, 2014 IEEE. IEEE, 2014.

[2] Singh, Ashish, and Kakali Chatterjee. "A secure multi-tier authentication scheme in cloud computing environment." Circuit, Power and Computing Technologies (ICCPCT), 2015 International Conference on. IEEE, 2015.

[3] Yang, Jen Ho, and Pei Yu Lin. "An ID-based user authentication scheme for cloud computing." Intelligent Information Hiding and Multimedia Signal Processing (IIH-MSP), 2014 Tenth International Conference on. IEEE, 2014.

[4] Chen, Tien-Ho, Hsiu-lien Yeh, and Wei-Kuan Shih. "An advanced ECC dynamic id-based remote mutual authentication scheme for cloud computing." Multimedia and Ubiquitous Engineering (MUE), 2011 5th FTRA International Conference on. IEEE, 2011.

[5] Tsai, Jia-Lun, and Nai-Wei Lo. "A privacy-aware authentication scheme for distributed mobile cloud computing services." IEEE systems journal 9.3 (2015): 805-815.
[6] Powell, Courtney, Takashi Aizawa, and Masaharu Munetomo. "Design of an SSO authentication infrastructure for heterogeneous inter-cloud environments." Cloud Networking (CloudNet), 2014 IEEE 3rd International Conference on. IEEE, 2014.

[7] Peng, Siwei. "An Id-based Multiple Authentication scheme against attacks in wireless sensor networks." Cloud Computing and Intelligent Systems (CCIS), 2012 IEEE 2nd International Conference on. Vol. 3. IEEE, 2012.

[8] Nguyen, Tien Dung, and Eui-Nam Huh. "A Dynamic ID-Based Authentication Scheme for M2M Communication of Healthcare Systems." Int. Arab J. Inf. Technol. 9.6 (2012): 511-519.

[9] Chu, Fuzhi, et al. "An improved identity authentication scheme for internet of things in heterogeneous networking environments." Network-Based Information Systems (NBiS), 2013 16th International Conference on. IEEE, 2013.

[10] Liu, Jing, Yang Xiao, and CL Philip Chen. "Authentication and access control in the internet of things." Distributed Computing Systems Workshops (ICDCSW), 2012 32nd International Conference on. IEEE, 2012.

[11] Jan, Mian Ahmad, et al. "A robust authentication scheme for observing resources in the internet of things environment." Trust, Security and Privacy in Computing and Communications (TrustCom), 2014 IEEE 13th International Conference on. IEEE, 2014.

[12] Shankar, K., and P. Eswaran. "RGB based multiple share creation in visual cryptography with aid of elliptic curve cryptography." China Communications 14.2 (2017): 118-130.

[13] Shankar, K., and P. Eswaran. "RGB-Based Secure Share Creation in Visual Cryptography Using Optimal Elliptic Curve Cryptography Technique." Journal of Circuits, Systems and Computers 25.11 (2016): 1650138. 